professor of clinical medicine in the University of Pennsylvania in 1884 marks the end of Osler's investi. gations as a pure scientist in the fields of zoology and physiology. In these fields he had achieved reputation as a trained microscopist and had made important contributions to knowledge. As W. T. Councilman said : "He could easily have become a great scientist, but he chose the path which led to the formation of the great clinician which he became; a worthy associate of the great men who have made English medicine famous" 15 .

Already at Montreal Osler had used the microscope in his pathological studies and continued to promote pathological research in association with clinical investigation in the Philadelphia and Baltimore periods. Thus his Goulstonian Lectures on malignant endocarditis ${ }^{16}$, based entirely on autopsies performed in Montreal, contained the first comprehensive account in English of the disease and are largely clinical and pathological, but not experimental. He suggested that malignant endocarditis was invariably of bacterial origin; he stained the organisms in the tissues and made a few inconclusive inoculation experiments ; but left to others the task of bacteriological investigation of this malady.

One of Osler's last pieces of microscopical investigation was his confirmation in 1886 of Laveran's discovery of the malarial parasite ${ }^{17}$. It was due to Osler's prompt appreciation of this discovery that the prevalent theory of a mysterious nocturnal 'miasma' was overthrown in the United States, and in his Baltimore Clinic, a few years later, he insisted that no diagnosis of malaria should be made without a microscopic examination of the blood. His hæmatological studies led him to take a special interest in diseases of the blood, and he described in 1902 "cyanosis with polycythæmia"18, since known as 'Osler's disease'. A hereditary malady characterized by multiple telangiectases associated with hæmorrhages $^{19}$ is also styled 'Osler's disease'.

Throughout his professional life, William Osler applied his scientific knowledge to the study of clinical disease and brought the laboratory to the bedside. His teaching in this respect has greatly influenced the progress of clinical medicine. He referred to this guiding star of his work in the follow' ing words : "To the physician particularly a scientific discipline is an incalculable gift which leavens his whole life, giving exactness to habits of thought and tempering the mind with that judicious faculty of distrust which can alone, amid the uncertainties of practice, make him wise unto salvation"20.

${ }^{2}$ Cushing, H., “The Life of Sir William Osler”, 1, 359 (Oxford, 1925)

'Canad. Naturalist and Quart. J. Sci., 1870-71, N.S., 5, 142 (Montreal)

3 ibid., N.S., 10, 399 (1883).

i ibid., N.S., 11, 473 (1881).

'Quart. J. Mic. Sci., Lond., N.S., 13, 307 (1873).

- Proc. Roy. Soc., 22, 391 (1873-74).

Trans. Assoc. Adv. Sci., Salem, Mass., 31, 512 (1883). "Wright, R. R., "Contributions to American Helminthology", Proc.

" "Verminous Bronchitis in Dogs", Veterinarian, Lond., 1, 387 (1877).

10 "On the Pathology of the So-called Pig Typhoid", Vet. J, and Ann. Comp. Path., Lond., 6, 385 (1878).

11 Trans. Path. Soc., Phila., 13, 222 (1885-87).

${ }_{12}$ Amer. Vet. Rev., N.Y., B, 6 (1882).

${ }^{18}$ Canada Med. and Sci. J., Montreal, 11, 325 (1882-83).

14 Canad. Naturalist, Montreal, N.S., 10, 406 (1883).

1s Johns Hopkins Hosp. Bull., 30, 197 (1919).

${ }^{10}$ Brit. Med. J., 1, 467, 522, 577 (1885).

${ }^{17}$ Trans. Path. Soc., Phila., 13, 255 (1885-87) and Brit. Med. J., 1, 556 (1887).

${ }^{18}$ Amer. J. Med. Sci., Phila., N.S., 128, 187 (1903).

${ }_{10}$ Johns Hopkins Hosp. Bull., 12, 333 (1901).

20 "The Leaven of Science", Univ. Med. Mag., Phila., 6, 573 (1893-94), and in "Aquanimitas" (London, 1904).

\section{SCIENCE OF THE AMARYLLIDS}

7 HE American Plant Life Society, organised for 1 the increase and diffusion of knowledge con. cerning plant-life, issues the year-book "Herbertia", which is devoted to the Amaryllids. Issues for 1946 and 1947 appeared together late in 1947 (from the Society, Box 2398, Stanford, California), and contain some useful papers of scientific interest. A detailed account of "the karyo-systematics of the sub-genus Ajax of the genus Narcissus" (Vol. 13, 1946) is contributed by A. Fernandes and Rosette Fernandes of Portugal. Of about eighteen species, fourteen are diploids, normally with $n=7$. Narcissus hispanicus is constituted of diploid and triploid forms, $N$. tortuosus is triploid, and $N$. bicolor tetraploid. Fifteen somatic chromosomes are found in $N$. asturiensis, N. minor, N. pumilus and N. pallidiflorus. Since all the species have the same karyotype, this supports the idea of Baker (1888) that the group is a single, very polymorphic Linnean species. The different forms have arisen by gene mutation and polyploidy.

A useful description of narcissus disease symptoms and control is given by Charles J. Gould (Vol. 13, 1946), with several photographs. Perhaps the most interesting to British readers is a virus disease rather appropriately named 'decline', but also known as 'white streak'. A corresponding paper on insect and mite pests of narcissus by $\mathrm{E}$. P. Breakey mentions the narcissus bulb fly, the lesser bulb fly and bulb mites, all of which are already known in Great Britain. It is usual to grow Amaryllids for their garden beauty, but M. J. Cox and M. M. MacMasters show (Vol. 14, 1947) that starch can also be prepared from the tuberous roots of Alstromeria aurantiaca and $A$. chilensis. Granules from the former are simple, but those from the latter have an unusual compound nature. Both give pastes which have similar charac. teristics to other root starches.

There are also shorter articles on all aspects of Amaryllid culture, breeding and classification.

\section{JOHN INNES HORTICULTURAL INSTITUTION}

GOR thirty-eight years, the John Innes Horticultural Institution has been carrying out detailed investi. gations in plant culture, genetics, breeding and other matters. 'J.I.' composts are now widely used and have perhaps done more than anything else to make the name of the Institution familiar to gardeners. The annual report for 1947 , recently issued, gives the results of many continued researches. M. B. Crane has obtained a certain amount of resistance to pear scab, Venturia pirina, from crosses between the pear varieties Giffard and Conference. Rogues in tomatoes are shown by D. Lewis to appear most frequently when the plants are grown at high temperatures $\left(26^{\circ} \mathrm{C}\right.$.). The same author has analysed seven X-ray induced mutations of the incompatibility gene of Enothera. They do not confer complete self-compatibility; but the work is being continued. $\mathbf{K}$. Mather has investigated the three types of gene which affect heterostyly in Primula sinensis. The difference of morphology and physiology between pin-eyed and thrum-eyed flowers is determined by the major genotype, and finally adjusted by the polygenotype. Miss A. Vines has studied breeding system and genetic isolation in Antirrhinum, and A. J. Bateman has 